MYKOLAI ORLENKO*, JULIA IVASHKO*

\section{Lighting devices in the Secession as the component of "Gesamtkunstwerk" and the issues of restoration}

Abstract

The Secession style was the last style with the highly expressed artist's individuality not only in architecture, paintings but also in lighting devices. One of the sources of the European Secession was the Japanese art: the inspiration that Japanese artists drew from nature, using its lines and forms was quickly assimilated by their European counterparts. The original features of Secession style in Ukraine present not only in facade's composition, decor but also in original lamps - for example in the interiors of the House of Chimaeras (in the entrance hall) or of the Kachkovsky Clyic stairwell, connected with the idea of "Gesamtkunstwerk" - the total space of art. During the time of Vladislav Gorodetsky, the author of the House of Chimaeras all the lamps in his own unusual house were designed by the author. During the restoring of the House with Chimaeras drawings or in the same style.

Keywords: lighting devices, Secession style, Ukraine, original traditions

\section{Introduction}

It is a well-known fact that every significant historical era is distinguished by the specific architectural forms, a stable system of functional, spatial, aesthetic characteristics which are generalized by the notion of the era style. The era style is a notion that, beside architecture, covers a wide range of ethical, aesthetic, artistic forms and reflects the level of the society material and spiritual culture.

The history of architecture is the history of consistent changes of stylistics - the whole set of means of expression of architectural forms, objectively comprising semantic features, signs of architectural and artistic image. Just due to these properties architecture it is nearly the most reliable source of objective information about the history of civilization and culture.

The architecture of the Secession of the late 19th - early 20th centuries attracts the attention of various scientific specialists not just by chance. Just the very style of the Secession became the sign of the era, nearly the highest rise of economy and culture, the architectural and town-planning activity of the time of for ation of devalu tions, material and technical and financial capabilities which stimulated investment processes in construction, favoured the devert, in particular, decorative, monumental, applied, arts related to the formation of the objective-spatial environment of human life activities.

It has been frequently said that the Secession was the las style with the highly expressed artist's individuality. Manifestations of the style uniqueness and originality are traced at different levels, which explains the fact why the professionals are so much interested in this style.

The issues of the Secession research are reduced to the following by different Ukrainian and foreign scientists:

cultural, aesthetic, artistic problems of the European Secession, its unique phenomeno were studied by F. Shmalenbah, R. Shmuzler, M. Reims, M. Pevzner, V. Hoffman, G.Yu. Sternin, A. Borisova, V.G. Lisowski, V.S. Goriyunov, M.P. Tubli;

- causes of emergence, specifics of manifestation, style originality, periodization, compositional principles of the Secession, its innovation communication between the Secession centre in different countries, Art Nouveau elements were studied by G.Yu. Sternin, E. A. Borisova J. V. Ivashko, E. I. Kyrychenko, D. V. Sarabianov, V. G. Lisovsky, V. V. Kyrylov, M. V. Nashchokin A. A. Berseneva O. V. Orelska, S. Grose, S. S. A. A. Ber B. B. O. V. Or, A. A. Bers analysis of the impact of external factors and interstyle processes, the connection of the Secesson with other styles are represented by the works of G. Yu. Sternin, E. A. Borisova, J. V. Ivashko, V.G. Lisovsky, V.S. Goriunov, . . Tubli, O. V. Orelska, G. A. Parkhomenko; - historical descriptions of the Secession objects, biographies of architects were studied by J. V. Ivashko, V.G. Lisovsky, B. M. Kirykov, beautiful and ominous, life and death, which can be clearly principal motto of this Secession became turning the usefu into the beautiful. At its early stage, the Secession was characterized by highlighted decorativeness, which was especially expressed in the design of interior items, in particular, in lighting devices, which acquired the unique features of the works of art Later, the style supporters started defending the form-creating value of design and material, and the fung the al and constructive basis of buildings started acquiring the style-forming sense.

The nature becmes the source of development of the interir objects in the Secession or objects in the Seccssion, which leads to the emergence of mushroum la Ther a There are severand explanstions for this: fist, the Secession artists adhered to the priple of avoidng using the architectural heritage of past centuries; second, the very romantic idyllic nature of Art Nouveau was encouraging this; thirdly, natural sciences developed just in the late 19th - early 20th centuries evolve

Many scientific sources (in particular, in scientific works of K. Frempton, H. Fudzioki, M. Speidel) contain the issue of a special role of the Eastern, first of all, Japanese culture in the establishment of the European Secession ("Art Nouveau") as an architecture and art style $[10,11,13]$. According to D. V. Sarabianov dialogue with the East, initiated by romanticism, continued by impressionists in painting and especially developed during the Secession period, was especially important for the Secession. Consequently, according to D. V. Sarabianov, the artistic trends that preceded the Secession and, at the same time, the discovery of the Eastern culture formed the historical preconditions of the Secession [7. p. 41]. According to E. I. Kyrychenko, stylization allowed the Secession to address many different sources, including the Japanese art not losing the integrity of style at the same the Japanese art, by the Europens in the late 19th century, in flexible lines of hapes and the Art Nouveau deor (which is seen also in flex-

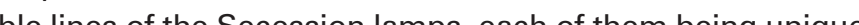
[4, c. 215] The in [4, c. 215]. The the inpotance of Japanese art tor Europe and the art and architecture of the Secession in the Japanese art was based on we unity with nature. According to M. Voloshin, acquaintance with Japanese art developed in European artists the aspiration for schematics and generalization without following the established rules and dogmas [4, c. 217]. Oriental (in particular, Japanese) art quickly spread in the USA and Europe in the 1850 s under the influence of the certain political events, social and spiritual circumstances.

M. V Nashchokina also drew attention to the presence of Orientalism in the Secession; she noted that the beginning of interest in Oriental art began from de Goncourt brothers. She emphasized that in many ways Orientalism favoured the development of the Secession aesthetics through borrowing the figurative language elements of oriental painting and ap-
S. S. Levoshko, O. B. Ushakova, M. V. Nashchokina, D. V. Malakov, O. G. Mokrousova, O. M. Drug, O. P. Serdiuk, G. S. Dukhovichny, T. V. Skibitska;

- studying and popularization of the Secession specific features in Ukraine (Ukrainian Art Nouveau) were performed by D. P. Galagan, L. M. Zhemchuzhykov, O. G. Slastion, G. K. Lukomsky, V. G. Krichevsky, K. V. Sherotsky, H. P. Serdiuk, K. M. Zhukov, D. M. Diachenko, M. G. Filiansky, S. P. Timoshenko, L I. Trush, V. K. Trotsenko, D. V. Antonovych, I. I. Levin V. F. Otchenashko:

modern studies of the regional specificity of the Secession of Ukraine are highlighted in the scientific works of lu. S. Biriulov, J. V. Ivashko, V. V. Kodin, S. V. Bilenkova, L. K. Polischuk, M. M. Stakian.

The causes of the Secession emergence in Ukraine on the background of the historica situation in Ukraine of the late 19th - early 20th centuries and impact of the external factors were highlighted by V. E. lasievich, J. V. Ivashko, H. P. Serdiuk, G. S. Duhovichny, T. V. Skibitska, lu. S. Biriulov, S. V. Bilenkova, L. K. Polischuk and M.M. Stakian. Specificity of the Secession as a style, features of this style manifestation in Ukraine as a whole and within individual centres, the Secession types with the description of typical objects were studied by V. E. lasievich, lu. S. Biriulov, H. P. Serdiuk, T. V. Skibitska, S. V. Bilenkova L. Kolischuk, M. M. Stakian. V. E. lasievich revealed the Secession periodization - two periods, early and late - and related them schools in the certain cities. The Secession centres in Ukraine were studied by V. E. lasievich, lu. S. Biriulov, S. V. Bilenkova, K. Polischuk, T. V. Skibitska, H. P. Serdiuk, M. M. Stakian, who classified the Secession centres by location in the cities, determined the specifics of the Art Nouveau centres within a single city. V. V. Chepelik was the first researcher to introduce the term "Ukrainian Art Nouveau", as the name of the main kind of the national-romantic modernist style in Ukraine and highlighted its specific features in detail.

2. Origins and specificity of the formation of Western European Secession and its manifestations in lighting devices

The Secession symbolism in the countries of Western Europe and the Russian has much in common: first of all, it is the opposition of rational and irrational, sublime and earthly, 
plied and decorative arts, was asserting the refined aesthetouveau which resisted centuries of prevalence of classical regularity [5, p. 202-203]. Japanese culture influenced the European Secession in several directions $[6,11]$. First of all, the Secession artists borrowed the tradition of poetizing nature in all its manifestations from the Japanese artists and poets. The usual lamp turns into flowers, on chimerically woven stems (as in the building in Kachkovsky Clinic at 33 Gonchara Street in Kyiv, designed of Kachkovsky clich architect by Polish architect Ignali Ledochovsky) (ill. 1), lighting lamps

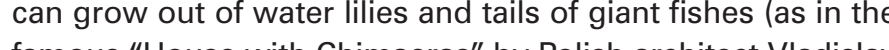
famous "House with Chimaeras" by Polish architect Vladislav
Gorodetsky Bankova Street 10 in Kyiv).

mote Japanese art, which had a special influence on interior design, including lighting, was made by a collector and a businessman Samuel Bing, who opened two stores in Paris, and in 1900, presented his "Art Nouveau" pavilion at the World Exhibition in Paris.

Partly from the wildlife, partly from Japanese engravings and hieroglyphs, a line typical for the Secession, a 'whiplash', was borrowed, which became widespread in the patterns of lighting devices [6]. Later in their works, the Secession artists addressed the natural origins as symbols of a harmonious, perfect environment, although they were against the litera citation of natural forms. However, the Secession architectural forms were able to form indirect association with natura forms: natural motifs are well-seen in Art Nouveau stained glass, in silhouettes in the interior items, in lamps, in wrought iron grates. In Art Nouveau, the border between artificial and natural environment has gradually disappeared, because the artificial environment acquired the features of "naturalness". In the Secession, a special place is occupied not by some real image but a characteristic symbol as a point of intersection of human inner world and the outside world, which was typical for Japanese art. For the Secession artist the object - even if it is a common stairwell lamp - is often perceived not as a real world image and implementation but as an immersion into the world of nature or unreal mysticism. That is why, the common Secession becomes a phenomenon similar to the common secession becomes a phenomenon similar to the Japanese principle of "wabi-sabi-poetic sorrow, loneliness, philosophical reflection in sollude when a beautiful thoughtful girl is holding a lower lamp and looking somewhere into the distance (as embodied by the architect $J$. Zekker in the
front lobby of Boruch Moroz profitable home at $61 / 11$ Volodymyrska St. in Kyiv).

myrska St. in Kyiv).
The 'Dialogue with the East', which lasted during the process The 'Dialogue with the East', which lasted during the process
of familiarization of the European artists, architects, collectors of familiarization of the European artists, architects, collectors
with the Eastern art, influenced the formation of European with the Eastern art, influenced the formation of European Art Nouveau [12]. A well-known Art Nouveau researcher,
D. V. Sarabianov, emphasized that the influence of Japanese D. V. Sarabianov, emphasized that the influence of Japanese art was felt at the beginning of the Secession style formation which led to the influence of the East, that is to say, from "inside the style", in all its manifestations, undergoing transformation in accordance with the European world perception [7]. There were several prerequisites for the Secession development in Ukraine, and they differed depending on the administrative and territorial specifics. The processes that took place

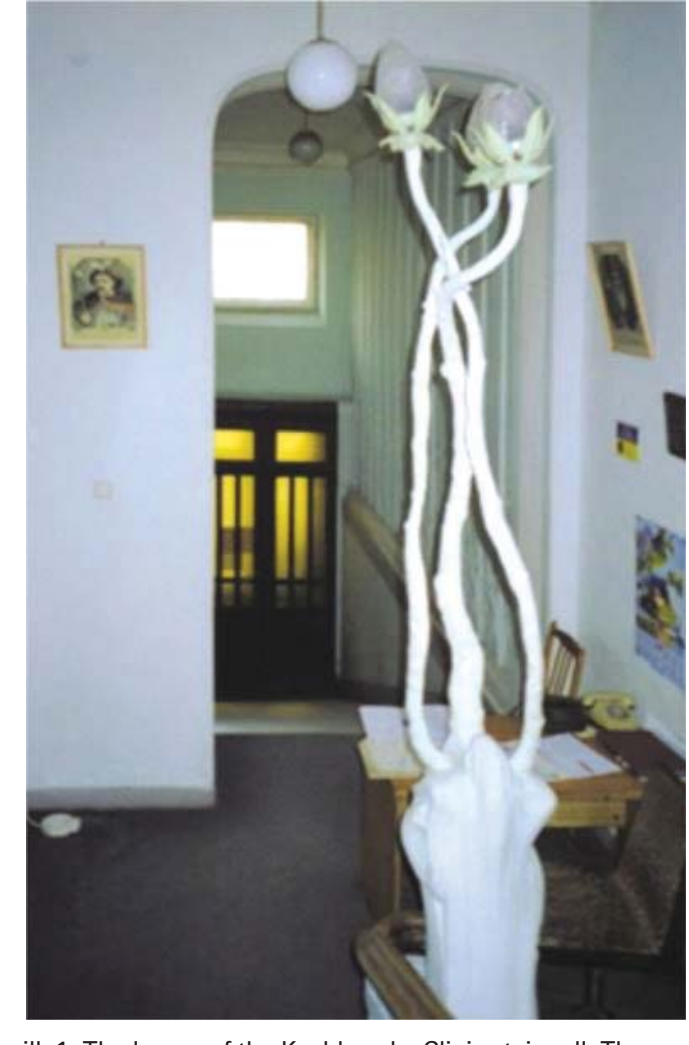

ill. 1. The lamps of the Kach
photo by J. Ivashko, 1998

in Austria-Hungary and Russia also influenced the emergence and spread of the Secession in Ukraine, with the only difference that the role of Lviv, Kyiv, Kharkiv and Odessa was much smaller than the role of Vienna, Prague, Budapest, Moscow, and St. Petersburg. The Secession arose on the territory of modern Ukrain in 1896-1898 years, even several years earlier, within the western centres, which at that time

ill. 2. The shell lamp in the entrance hall of the House with
Chimaeras. The archive photo of the early 20 th century

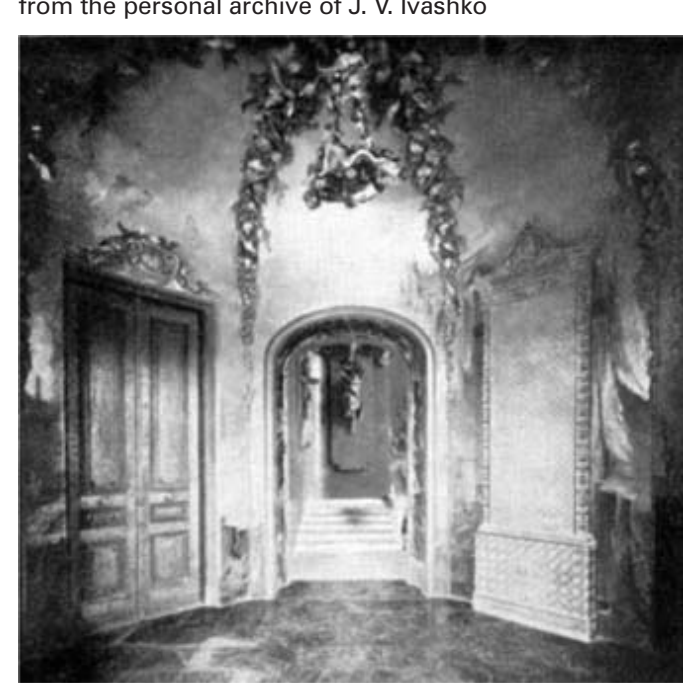

belonged administratively to the Austrian-Hungarian Emle popularity in all the Art Nouveau centres, except for the western ones, began to decrease. In the same way as in the European countries, the development of Secession in Ukraine took place on the background of rapid economic development, the activity of the new social class, the bourgeoisie, and was connected with the implementation of a large number of technical inventions. In scientific sources, it is possible to find rather detailed information on lighting devices of Art Nouveau age, examples of origina Art Nouveau lamps in Kyiv are much less knles - mostly due to the fact that in the most cities of mown Eastern Ulraine, Art Nouveau was expressed primaly That is why the oring That is why the onigna lamps in Kyiv byllings should be especially highlighted. There are several such objects. For example, he famous Polish architect Vladislav Gorodetsky, even having deviated from the Secession canons in the House of Chimaeras, however, kept the basic principle of the idea put forward by the apologist Henry Van de Velda; was the idea of "Gesamtkunstwerk" - the total space of art when the decoration of walls and ceilings, furnishings and even the inhabitants' clothes are merged into one unit (ill. 2). In the House of Chimaeras, like in a house owned by A. Van de Velde in Ukkle, picturesque panels on the walls and ceiling combine with sculptures and bas-reliefs dedicated to animal underwater and terrestrial worlds and hunting attributes. Round in the plan, the hall is covered with the vaulted ceiling divided into eight faces, along which a giant octopus spread its tentacles, and in the centre a large lamp in the shape of a shell is mounted (ill. 2). Four-storied parade staircases are illuminated with a large window from the side, and the centre of the staircase is a sculptural composition of two huge, swirling fishtails overtaken by water-lilies (ill. 3).

In the past, water lilies had white matte fixtures mounted into them in the form of bullets with electric lamps.

Kyiv residents know less about the interior of the former Kachkovsky Clinic on Gonchara Street, 33 with a flower lo Kyiv residents know Iass about the interior of the former in the form of three int

According to the general style of the premises, in 2001 the specialists of the "UkrNDIproektrestavratsiya" Institute developed the lighting devices of Rodzianko residential building at Yaroslaviv Val St., 14-b with modification of the homeowner's ises to be used as a chamber theatre "Susyriya" (ill. 4, 5).

3. The experience of restoration of lighting devices of modern items

The issue of the correlation of the required lighting and the object authenticity is especially important for the objects of restoration, many of which were illuminated in accordance with that time requirements. We should consider solving the issues of lighting on the example of the famous "Hous with Chimaeras", modified to be used as the residence of

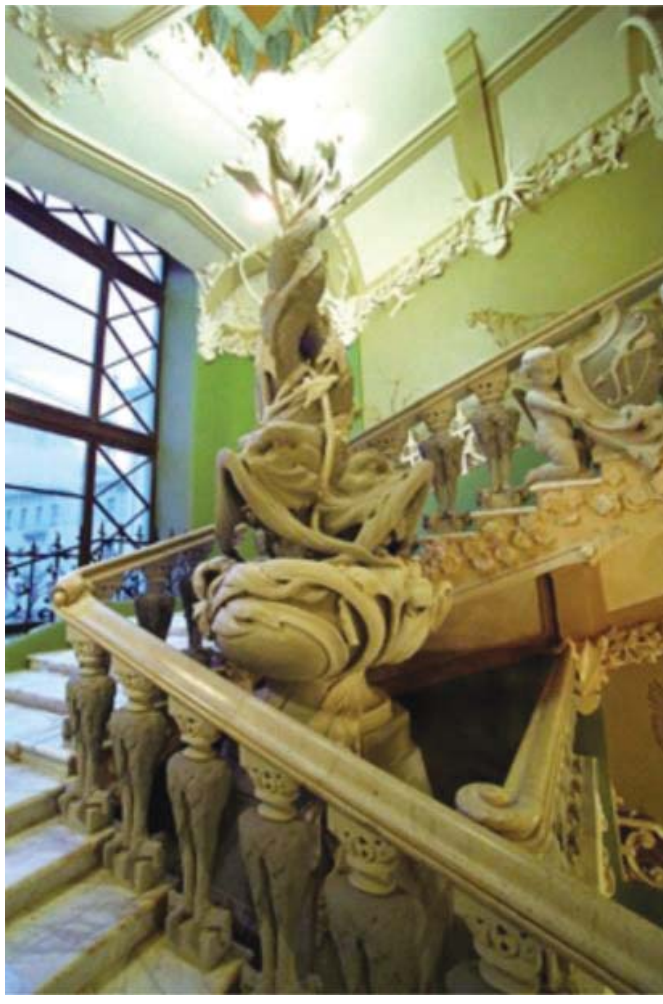

ili. 3. The lamp with fishes in the House with chimaeras.
The photo from the funds of "Ukrrestavratsisya" corporation

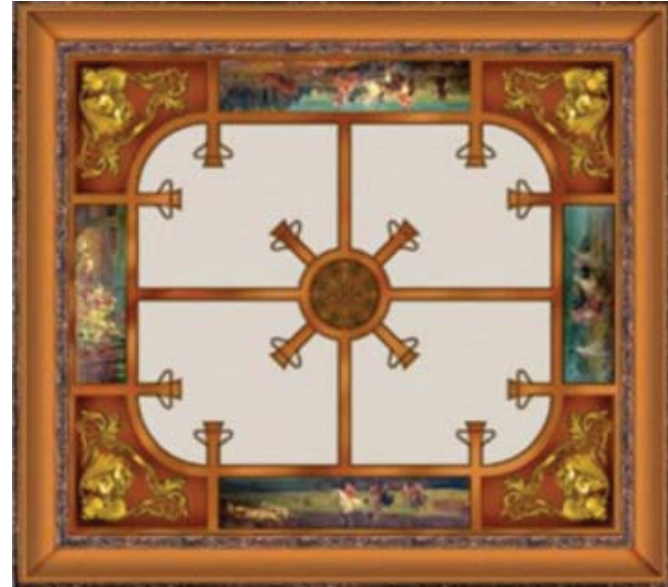

ill. 4. The glass globe of the 'English office' of the for-
mer Rodzianka flat. The drawing from the funds of

the President of Ukraine. Since in the Soviet imes, the government polyclinic was located in the house, typical standard Soviet lightin devices were installed everywhere and $\mathrm{n}$ original lamp from the time of $\mathrm{V}$. Gorodetsky was preserved. Therefore, during the restoration and recovery work with the new building adaptation, our specialists had to study the enormous number of archival sources and perform the research of the original lighting system to provide the authentic look of the re- 


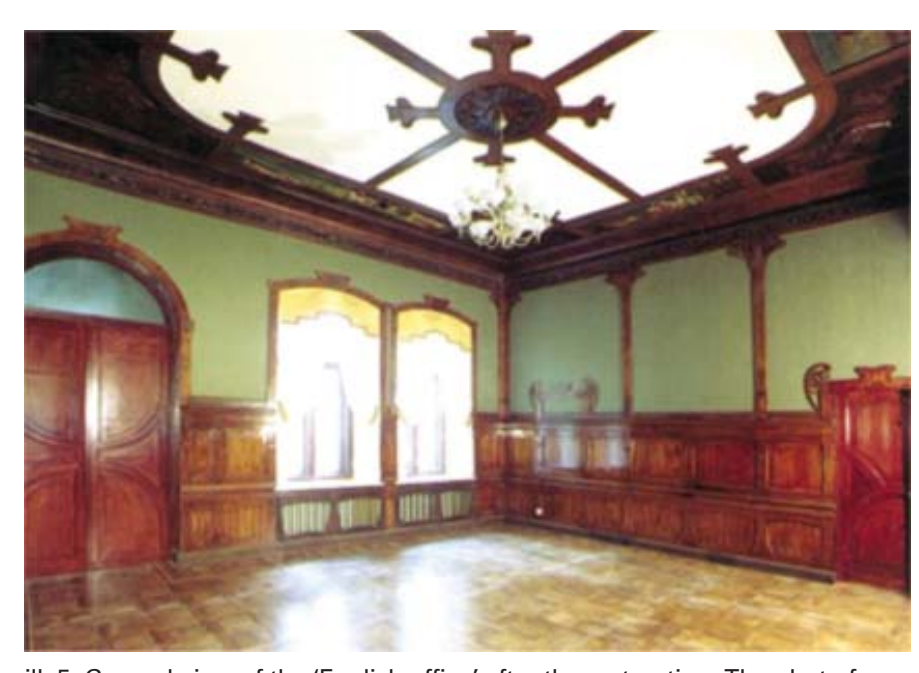

ill. 5. General view of the 'English office' after the restoration. The photo from
the personal archive of $\lrcorner V$. vasshko

stored premises. In total, according to individual drawings, 66 chandeliers and lamp-brackets (15 chandeliers of ten types, 51 lamp-brackets of seven types) were made, besides 95 chandeliers and lamp-brackets (23 chandeliers of seventeen types, 72 lamp-brackets of thirteen types) were manufactured (ill. 6). Consequently, we can state that the lighting system of the building taking into consideration its uniqueness was exclusive, which determined the variety of types of lighting devices used.

The main solution of the lighting system of the House with Chimaeras was that, during the time of Gorodetsky, all the lamps were designed by the author, and the restorers of the "Ukrrestavratsiya" corporation, had to develop them according to the author's drawings. The authors of the designed devices were famous artists S. Adamenko and M. Ralko. The entire wiring was replaced, and all lighting devices were arranged in those places where they were installed at the time of V. Gorodetsky. The glass globes, identical to the original initial ones in design, were made in Italy from Venetian glass (" $\mathrm{Mu}$ rano") of various shades; other domestic chandeliers were adorned with Czech crystal in combination with bronze and brass. In cases where the archival photograph of the pre and brass. In cases where es interiors were presed, facture la ws according to their initial appearance, including the use of horns of some particular anmal (for Gorodetsky was a hing on the lamps (ch miner pre mises were selected depending on the lamps (chandeliers and lamp-brackets) of the main premises and based on the general style of interiors. Moreover, chandeliers from alabaster RP268A and 268E, Alabastro crema and lamp-brackets from alabaster 268N Alabastro crema were used in the lobby and the rooms of the firs and second floors.

The most difficult task for restorers was to modify the former profitable home of V. Gorodetsky to be used as the State residence; for example, in order to hide communication lines on the floor, its level was raised by $40 \mathrm{~cm}$.

The project of electric lighting was developed on the basis of the customer's order, the order of Svetlotechnika Ltd. (where the installation sites and lamp power were specified), and drawings of the architectural and construction part of the project. The project provided for the arrangement of working, emergency and operational lighting systems, and the choice of types of individual interior lighting devices. The installation of lighting devices with incandescent lamps (in the main premises of the Residence) and lighting devices with fluorescent lamps (in the auxiliary premises) was provided in the premises of the House with Chimaeras In order to receive and distribute power, switchboards with automatic and difporential switches were mounted. It was assumed that during the powere emas assumutdown the lighting automer to the res or pow to the roserved power supply system, the local lamp control was provided, via switches. The electric lighting system of equipment in special premises was separated from all electrical networks of the bullding and connected through network filters. Electrical wiring in special premises, as well as supply network were installed with the use of the screened wires and cables in PVC insulation in the meta sleeve, hidden behind the suspended ceiling or in steel pipes in the floor of the upper floors (to the chandeliers). In the pipes leading to the chandeliers, the backup wire of the same section was laid.

Separate working drawings of electric lighting of the cellar, basement floor, the first and fifth floors of the "House with Chimaeras" were developed. Two spiral lamps with argon filler 60 100, 150-1 and 40, luminescent mercury low pressure lamps LB20, LB40 were used.

In the former Gorodetsky's dining room, elk horns, brass and bronze, reproduced accord ing to the archival photographs, according to the authentic apperance of interiors, wing to used in the chaper used for lamp-brackets of $B 5$ type $(5$ latso used chack 10 ha 60 wmp bracke of $B 6$. In the ror 6 and 6 lanp-brackets of B6. Inthe room with paintings on the ceilling, dedicated to hunting, two chandeliers of type L8 with mouflon horns and lamp-brackets of $B 8$ (6 pieces), B17 (6 pieces) and B18 (6 pieces) types with moutlon horns were installed.

The project provided for the backlight of the facades, the electrical wiring performed by a cable openly on the wall. The control of external lighting of the facades was provided with the help of photocells located on the building facade (the lighting program was installed in a separate cabinet). Protective grounding was performed by connecting to the power network zero wire. During solving
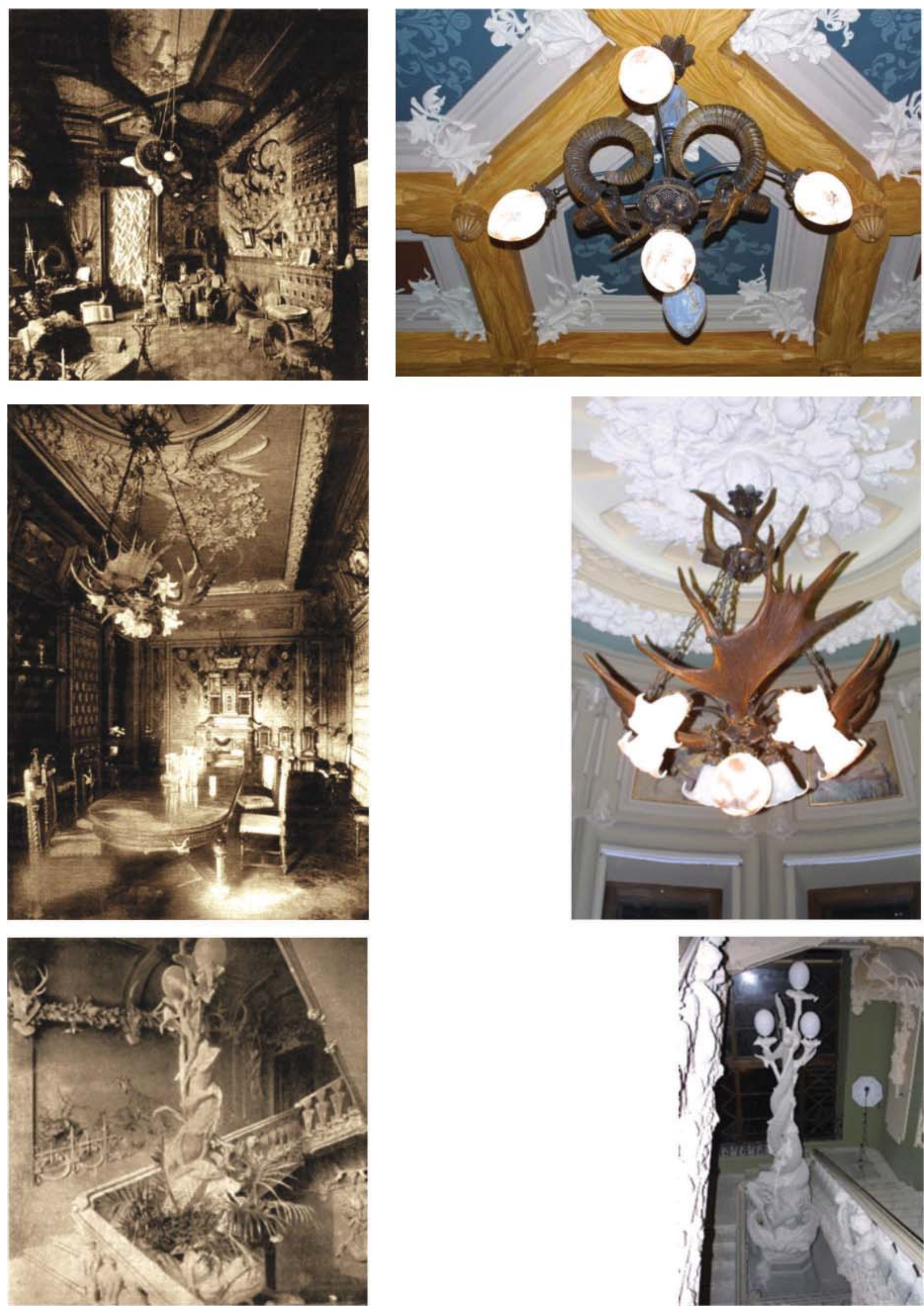
the system of illumination of the house facades, the task was to reveal and emphasize maximally the unique architectural plastic of all facades and the individuality of the style of "House with Chimaeras". A project of architectural external lighting was developed, which provided for the arrangement of the backlight on the windowsills and on separate pillars located around the house perimeter, where powerful searchlights are installed.

\section{GENERAL CONCLUSIONS}

Lighting plays an important role in the perception of the architectural object and adds to its attractiveness for tourists to the large extent. This fact is successfully used to illuminate the unique objects of Krakow, Vienna, Budapest, and Prague. The complexity of the restoration of the Secession objects is in the fact that restorers have a task to achieve maximal authenticity, including the smallest details, and Secession is just characterized by the increased plasticity and complex detailing. Just in Secession that individual design of interior elements, especially lighting devices, becomes very significant, which is clearly seen from the examples of the objects restored by the specialists of "Ukrrestavratsiya" corporation [6]. The European Secession left a noticeable track in the world culture, in the first turn, due to the fact that it transformed every element into a work of art. In distinction from the previous historicism-eclecticism and the following functionalismavant-garde trends, that actively used numerous elements of furnishings, the Secession praised the individual details, each of them was considered as an integral part of the continuous art space where all the components are equally important a building in general, a lamp, a door handle, and the inhabitants' clothes.

Such a refined and artistic attitude to the elements of furniture and the air of individuality had a special impact on the design of lighting devices that were turned in the work of art. The Ukrainian Secession covers fewer examples of the origi- nal lighting devices in comparison with the European countries, but the examples shown are considered the best examples of the interiors of Kyiv, Lviv, Kharkiv and Vinnitsa. Such prominent objects in Kyiv include "The House with Chimaeras" by the architect Vladislav Gorodetsky, and all the objects by Ignatii Ledohovsky, that is why the task of restoration of these buildings was assigned to the professionals, and all work was performed in accordance with the international restoration principles.

\section{BIBLIOGRAPHY}

[1] Böcklin. The Album. - M.: Belyi Gorod, 2001. - 48 p.

[2] Berldsley, Aubrey. Drawings. Prose. Poems. Aphorisms. Letters Memories and articles about Beardsley. - Moscow: Igra-Tekhnika, 1992. - 288 p.

[3] Velichko S. Once there lived such a person: Shehktel // Velichko S. - Moscowskoye Nasledie. - 2009. - No. 10. - P.26-43.

[4] Kyrychenko E. I. Russian Architecture of the 1830-1910s / levgenia Ivanovna Kyrychenko. - Moscow: Iskusstvo, 1982. - 400 p., illustrated.

[5] Nashchokina M.V. Face to face with the muse of the architectural history / Maria Vladimirovna Nashchokina. - Moscow: Uley, 2008. -510 p.

[6] Orlenko M. I., Ivashko J. V., Li Shuan. Reincarnation of Northern National Romanticism. Investigation and experience of restoration of objects // Main redactor Prof. M. Dyomin.

/ Mykolai Orlenko, Julia Ivashko, Li Shuan. - Kyiv: Phenix, 2016. - 288 p.

[7] Sarabianov D.V. Art Nouveau style / D.V. Sarabianov. - Moscow: Iskusstvo, 1989. - 295 p., II.

[8] Ushakova O. B. Interaction of historism and new style in the Baltic Art Nouveau / Olga Ushakova // Architecture of the Modernist Epoch in the Baltic Countries. - St. Petersburg: NIITIAG RAASN, 2013. - p.44-45.

[9] Far-Becker G. Japanese Engraving/G. Far-Becker. Tashen/Art-Rodnik. - $2005-200$ p.

10. Frempton K. Modern Architecture: A Critical View on the History of Development/Kenneth Frempton; [ed. By V. L. Hayt]. - Moscow: Stroyizdat, 1990. - 535 p.

[11] Fudzioka H. A New View of the Tradition/H. Fudzioka // UNESCO Courier. - 1990 - October. - P. 18-19

[12] The Reciting Reader. A.K./ [no year, no edition]. - 618 p.

[13] Speidel M. Winning Wave / M. Spaidel // UNESCO Courier, 1990. - October. - P. 13-17. 